\title{
ANALISIS DAYA SAING USAHATANI KELAPA SAWIT RAKYAT DI KECAMATAN SEKERNAN KABUPATEN MUARO JAMBI
}

\author{
Esra Natalina Sianturi ${ }^{1}$, Saidin Nainggolan ${ }^{2)}$ dan Elwamendri ${ }^{3)}$ \\ 1) Alumni Program Studi Agribisnis Fakultas Pertanian Universitas Jambi \\ 2) Staf Pengajar Program Studi Agribisnis Fakultas Pertanian Universitas Jambi \\ E-mail : esranatalinasianturi@yahoo.com
}

\begin{abstract}
ABSTRAK
Penelitian ini bertujuan untuk menganalisis (1) daya saing (keunggulan kompetitif dan keunggulan komparatif), (2) dampak kebijakan pemerintah terhadap output dan input, dan (3) sensitivitas daya saing pada usahatani kelapa sawit rakyat di Kabupaten Muaro Jambi dengan lokus penelitian Kecamatan Sekernan. Metode analisis yang digunakan adalah Matriks Analisis Kebijakan (Policy Analysis Matrix). Penelitian dilaksanakan pada tahun 2019. Hasil penelitian menunjukkan bahwa: (1) Usahatani kelapa sawit rakyat di Kecamatan Sekernan Kabupaten Muaro Jambi memiliki daya saing dengan indikator keunggulan kompetitif $P C R=0,13$ dan indikator keunggulan komparatif dan DRCR $=0,27$ (2) Kebijakan pemerintah pada input-output usahatani sawit sudah cukup berjalan dengan secara efektif dan (3) Usahatani kelapa sawit rakyat masih memiliki daya saing walaupun terjadi kenaikan harga input pupuk.
\end{abstract}

Kata Kunci: Kelapa Sawit, Daya Saing, Keunggulan Komparatif, Keunggulan Kompetitif, Policy Analysis Matrix (PAM)

\begin{abstract}
ABSTRAK
This research is aimed to: 1) competitiveness (competitive advantage and comparative advantage), 2) the impact of government policies on outputs and inputs, and 3) sensitivity of competitiveness in smallholder oil palm farms in Muaro Jambi with the locus district research center. The analytical method used is the Policy Analysis Matrix. The research was conducted in 2019. The results showed that 1) smallholder palm oil farming ini Sekernan, Muaro Jambi has competitiveness with an indicator of competitive advantage PCR $=0,13$ and indicators of comparative advantage $\mathrm{DRCR}=0,27 ; 2$ ) government policies on palm oil farming inputs and outputs have been quite effective and 3 ) smallholder palm oil farming still has competitiveness despite the increase in fertilizer input prices.
\end{abstract}

Kata Kunci : Palm Oil, Competitiveness, comparative Advantage, Competitive Advantage, Policy Analysis Matrix (PAM)

\section{PENDAHULUAN}

Indonesia mampu menghasilkan sekitar 35,5 juta ton minyak sawit yang terdiri dari 32,5 juta ton minyak sawit mentah dan 3 juta ton minyak inti. Pada tahun yang sama produksi minyak sawit dunia mencapai 66,8 juta ton, sehingga pangsa Indonesia adalah sekitar 53 persen dari produksi minyak sawit dunia (Kementrian Pertanian, 2016). Sebagai negara agraris, Indonesia memiliki daya saing sebagai produsen komoditas pertanian, terutama dari subsektor perkebunan yang selama ini dijadikan sebagai komoditas andalan ekspor dalam perdagangan internasional, baik dari keunggulan komparatif maupun keunggulan kompetitif (Rosdiana Sari, 2018).

Kelapa sawit merupakan komoditas perkebunan Indonesia yang berorientasi ekspor, maka komoditas sawit tidak terlepas dari campur tangan pemerintah yaitu berupa kebijakan pemerintah. Kebijakan tersebut erat kaitannya dengan input-output dalam pengusahaan sawit. Kebijakan-kebijakan pemerintah tersebut akan mempengaruhi daya saing komoditas yang mencakup keunggulan komparatif dan keunggulan kompetitif komoditas sawit. Harga kelapa sawit (wujud CPO) tahun 2016 baik dipasar domestik (spot Medan) maupun di pasar dunia ( spot Rotterdam) menunjukkan adanya pemulihan pasar, setelah terpuruk di tahun-tahun sebelumnya. Tingkat konsumsi minyak goreng 
perkapita pada tahun 2016 bedasarkan hasil Susenas - BPS sebesar 14,6 kg/kapita, sehingga total konsumsi domestik pada tahun tersebut sebesar 3,78 juta ton minyak goreng atau setara dengan 5,53 juta ton kelapa sawit (Pusat Data dan Sistem Informasi Pertanian, 2017). Harga sawit umur 9 tahun Rp.1.333,62/kg dan sawit umur 10-20 tahun Rp.1.364,62/kg. Harga minyak sawit mentah (CPO) diterapkan Rp.6.577,48/kg dan harga kernel Rp.3.909,99/kg dengan indeks K 84,00\%.

Provinsi Jambi termasuk kedalam sentra produksi kelapa sawit. Perkebunan sawit yang ada di Provinsi Jambi didominasi oleh perkebunan sawit yang mayoritasnya diusahakan oleh perkebunan sawit rakyat dan hampir setiap kabupaten yang ada di Provinsi Jambi mengusahakan sawit sebagai mata pencaharian utama. Provinsi jambi dalam hal perkebunan merupakan pada umunya adalah perkebunan rakyat. Produksi perkebunan rakyat terbesar adalah karet yang memiliki luas tanam 663.981 Ha dengan produksi 333.168 ton pada tahun 2016. Komoditas andalanya yaitu kelapa sawit dengan produksi 1.032.171 ton. Pada perkembangan luas lahan perkebunan kelapa sawit di Provinsi Jambi mengalami peningkatan dari tahun ke tahun. Pada tahun 2013 perkembnagan luas lahan mencapai 657.929 ha atau sekitar $18.67 \%$ selanjutnya pada tahun 2017 meningkat luas lahan perkebunan sawit mencapai 755.522 atau sekitar $21.44 \%$ denga begitu luas lahan perkebunan di Provinsi Jambi mengalami peningkatan, tetapi banyak meragukan apakah juga terjadi peningkatan daya saing.

Pengukuran daya saing usahatani kebun sawit rakyat penting dilakukan untuk mengukur kemampuan suatu komoditas usahatani kebun sawit rakyat dalam menghasilkan keuntungan yang maksimum dari usahatani tersebut. Daya saing petani adalah tingkat kemampuan petani untuk memproduksi hasil pertanian bedasarkan keunggulan biaya (cost advantage). Keunggulan biaya tidak berarti bahwa biaya produksi per unit output harus murah, tetapi yang penting adalah biaya produksi per unit output petani Indonesia lebih murah dibandingkan negara-negara lain untuk memproduksi produk pertanian dengan mutu hasil setara. Jika keuntungan suatu komoditas mempunyai daya saing jika usaha tersebut mampu mempertahankan profitabilitas atau keuntungannya dan pangsa pasarnya. Daya saing dapat diukur melalui dua pendekatan yaitu keunggulan komparatif dan keunggulan kompetitif. Keunggulan komparatif mengukur efisiensi suatu komoditas berdasarkan analisis ekonomi dengan memakai harga bayangan, sementara keunggulan kompetitif digunakan untuk mengukur kelayakan suatu aktifitas atau keuntungan privat yang dihitung bedasarkan harga privat. Daya saing dapat diukur melalui dua pendekatan yaitu keunggulan komparatif dan keunggulan kompetitif. Keunggulan komparatif mengukur efeisiensi suatu komoditas berdasarkan analisis ekonomi dengan memakai harga bayangan, sementara keunggulan kompetitif digunakan untuk mengukur kelayakan suatu aktifitas atau keuntungan privat yang dihitung bedasarkan harga privat.

\section{METODE PENELITIAN}

Penentuan lokasi penelitian dilakukan secara sengaja (purposive). Metode penentuan responden dengan menggunakan metode simple random sampling. Dengan menentukan sample petani yang tanamannya sudah menghasilkan (TM). Sample yang digunakan berjumlah 51 petani responden. Penelitian ini dilaksanakan di Kecamatan Sekernan Kabupaten Muaro Jambi. Dengan desa yang terpilih yaitu desa Bukit Baling, Suak Putat, dan Suko Awin Jaya. Penelitian ini dilaksanakan pada bulan 12 Agustus - 12 September 2019.

Metode yang digunakan dalam Pengumpulan data primer adalah metode pengamatan langsung berstruktur, observasi dan wawancara. Metode pengamatan langsung berstruktur yaitu pengamatan yang telah direncanakan dan mengetahui apa yang akan diteliti. Metode observasi yaitu pengamatan dan penelitian langsung ke petani kelapa sawit rakyat. Metode wawancara yaitu mengajukan pertanyaan dengan menggunakan kuesioner sebagai panduan pertanyaan yang telah disusun secara langsung kepada petani sampel di daerah penelitian. Sedangkan metode pengambilan data sekunder diperoleh dengan cara mengutip, menyalin, dan mengolah serta mempelajari data dari instansi terkait, studi literatur, jurnal, laporan dan hasil penelitian sebelumnya yang berhubungan dengan penelitian.

Analisis data menggunakan PAM (Policy Analysis Matrix). PAM mengukur keuntungan privat (harga aktual) dan harga sosial (harga efisiensi). Metode ini menunjukkan pendapatan, biaya, dan keuntungan aktual yang diperoleh, dan membandingkannya dengan nilai-nilai tersebut seandainya komoditas dan sumberdaya dihitung pada tingkat harga internasional atau Domestic Opportunity 
Cost. Perhitungan model PAM dilakukan dengan menggunakan matrik PAM yang dapat dilihat pada tabel berikut ini :

Tabel 1. Format Dasar Matrik Analisis Kebijakan (PAM)

\begin{tabular}{|c|c|c|c|c|c|}
\hline \multirow{2}{*}{ No } & \multirow{2}{*}{ Uraian } & \multirow{2}{*}{ Pendapatan } & \multicolumn{2}{|c|}{ Biaya } & \multirow{2}{*}{ Keuntungan } \\
\hline & & & Tradeable & Non-Tradeable & \\
\hline 1 & Harga Pasar & A & $\mathrm{B}$ & $\mathrm{C}$ & $\mathrm{D}$ \\
\hline 2 & Harga Sosial & $\mathrm{E}$ & $\mathrm{F}$ & $\mathrm{G}$ & $\mathrm{H}$ \\
\hline 3 & Divergensi & I & $\mathrm{J}$ & $\mathrm{K}$ & $\mathrm{L}$ \\
\hline \multicolumn{3}{|c|}{$\begin{array}{l}\text { Keuntungan Finansial (D) } \\
\text { Keuntungan Ekonomi (H) } \\
\text { Rasio Biaya Privat (PCR) } \\
\text { Rasio BSD (DRC) }\end{array}$} & \multicolumn{2}{|c|}{$\begin{array}{l}=A-(B+C) \\
=E-(F+G) \\
=C /(A-B) \\
=G /(E-F)\end{array}$} & \\
\hline
\end{tabular}

Baris pertama dari PAM adalah perhitungan dengan harga privat atau harga finansial, yaitu harga yang betul-betul diterima atau dibayarkan oleh pelaku ekonomi. Baris kedua merupakan perhitungan yang didasarkan pada harga sosial (shadow price), harga yang menggambarkan nilai sosial atau nilai ekonomi yang sesungguhnya bagi unsur-unsur biaya maupun hasil. Baris ketiga disebut sebagai baris effect of divergence merupakan perbedaan perhitungan dari harga privat dengan harga sosial sebagai akibat dari dampak kebijaksanaan pemerintah atau distorsi pasar yang ada.

\section{Analisis Keunggulan Komparatif Dan Keunggulan Kompetitif}

Domestik Resource Cost Ratio (DRCR) adalah indikator keunggulan komparatif, yang menunjukkan jumlah sumberdaya domestik yang dapat dihemat untuk menghasilkan satu unit devisa. Sistem mempunyai keunggulan komparatif jika $\mathrm{DRC}<1$, dan jika DRC $>1$ tidak mempunyai keunggulan komparatif. Privat Cost Ratio (PCR) adalah indikator profitabilitas privat yang menunjukkan kemampuan sistem komoditas untuk membayae biaya sumberdaya domestic dan tetap kompetitif. Jika PCR $<1$, berarti sistem komoditas memiliki keunggulan kompettitif dan jika PCR $>1$ berarti komoditas tidak memiliki keunggulan kompetitif.

\section{HASIL DAN PEMBAHASAN}

Analisis Daya Saing Dengan Pendekatan Policy Analysis Matrix (PAM). Perbedaan kedua harga disebut divergensi yang merupakan dampak kebijakan pemerintah, dan distorsi di pasar input dan output yang ditunjukkan Tabel 2.

Tabel 2. Hasil Perhitungan PAM (Policy Analysis Matrix) Usahatani Sawit di Daerah Penelitian, Tahun 2019

\begin{tabular}{lcccc}
\hline \multirow{2}{*}{ Uraian } & \multirow{2}{*}{ Penerimaan } & \multicolumn{2}{c}{ Biaya Input } & Keuntungan \\
\cline { 4 - 5 } & & Tradeable & Non Tradeable & \\
\hline Privat & 50.748 .863 & 811.804 & 6.986 .854 & 42.953 .200 \\
Sosial & 32.896 .468 & 1.466 .034 & 8.593 .398 & 22.838 .066 \\
Divergensi & 17.852 .395 & -654.230 & -1.606 .544 & 20.115 .134 \\
\hline
\end{tabular}

Tabel 2 hasil perhitungan analisis PAM menunjukkan bahwa sistem komoditas sawit di Kecamatan Sekernan menguntungkan baik secara finansial maupun ekonomi. Keuntungan privat dan keuntungan sosial usahatani sawit di Kecamatan Sekernan menunjukan nilai positif, itu berarti usahatani sawit layak untuk diusahakan atau dikembangkan. Dimana penerimaan ditingkat harga privat sebesar 50,87 juta rupiah per tahun, sedangkan penerimaan ditingkat harga sosial sebesar 32,89 juta rupiah per tahun. Nilai divergensi yang positif yaitu sebesar 17.85 juta rupiah artinya kebijakan pemerintah telah mampu memberikan kontribusi yang efektif terhadap penerimaan dan 
pengeluaran dalam usahatani sawit di Kecamatan Sekernan. Hal ini sejalan dengan penelitian Palupi Permata,et.al (2013:158) dengan nilai divergensi yang bernilai postif sebesar 153,28 juta rupiahper hektar.

\section{Keunggulan Komparatif}

Tabel. 3 Rata-rata Biaya Input Bedasarkan Harga Privat di Daerah Penelitian, Tahun 2019

\begin{tabular}{lccc}
\hline \multicolumn{1}{c}{ Uraian } & \multicolumn{2}{c}{ Finansial (Harga Sosial) } \\
Input Tradeable & Total \\
\hline Input Produksi & & & \\
Bibit & 565.953 & & 565.953 \\
Pupuk & & 309.673 & 1.067 .838 \\
1. Urea & 758.164 & 672.627 & 2.319 .405 \\
2.KCL & 1.646 .777 & 467.164 & 1.610 .912 \\
3.NPK & 1.143 .747 & & \\
Obat-obatan & & 8.889 & 46.638 \\
1.Gramaxone & 37.748 & 6.646 & 34.873 \\
2.Rondap & 28.226 & & \\
Biaya Peralatan & & & 21.792 \\
Cangkul & 21.792 & & 16.187 \\
Dodos & 16.187 & & 12.290 \\
Egrek & 12.290 & & 34.285 \\
Angkong & 34.285 & & 19.327 \\
Tojok & 19.327 & & 6.617 \\
Gancu & 6.617 & & \\
Tenaga Kerja & & & 558.781 \\
Dalam Keluarga & 558.781 & & 3.743 .504 \\
\hline Luar keluarga & 3.743 .504 & 1.466 .034 & 10.058 .402 \\
\hline Jumlah & 8.593 .398 &
\end{tabular}

Tabel 3 menunjukkan total biaya sumberdaya domestik pada usahatani sawit di daerah penelitian sebesar 10,05 juta rupiah dan total biaya sumberdaya asing usahatani sawit sebesar 1,46 juta rupiah Total biaya sumberdaya asing usahatani sawit di daerah penelitian lebih kecil dibandingkan dengan total biaya sumberdaya domestik dikarenakan oleh alokasi sumberdaya asing hanya terdapat dalam 2 input saja, yaitu pupuk dan pestisida. Dalam perhitungan harga sosial untuk barang non tradable berbeda dengan tradable. Seperti halnya barang tradable, harga privat untuk non tradable diambil dari tabel privat budget ditingkat petani. Namun tidak ada harga dunia (border price) untuk non tradable yang bisa digunakan sebagai harga efeisiensi, seperti halnya barang tradable. Biaya input non tradable tidak bisa secara langsung dibuat kolom tersendiri dalam tabel PAM karena tidak ada cara langsung menilai harga sosial input jenis ini.

Hasil perhitungan indikator rasio pengukur daya saing menghasilkan nilai DRCR untuk usahatani sawit di daerah penelitian kurang dari satu yaitu sebesar 0,2734 menunjukkan usahatani sawit di Kecamatan Sekernan efisien dalam penggunaan sumberdaya domestik dan memiliki keunggulan komparatif. Nilai 0,2734 mempunyai arti bahwa untuk menghasilkan satu satuan nilai tambah output pada harga sosial hanya membutuhkan sumberdaya domestik sebesar $27,34 \%$ atau setiap satu satuan rupiah produksi yang dihasilkan akan memberikan nilai tambah secara ekonomis (harga sosial) sebesar 0,2734 rupiah. Hal ini sejalan dengan penelitian yang dilakukan oleh Aprizal et.al (2013:143) bahwa usahatani sawit memiliki nilai DRCR $<1$ yaitu 0,72 . Semakin rendah nilai koefisien DRCR berarti desa tersebut mampu bertahan walaupun tanpa bantuan pemerintah karena memilki sumber daya domestik yang diperlukan bagi pengembangan komoditas kelapa sawit. 


\section{Keunggulan Kompetitif}

Tabel 4. Rata-rata Biaya Input Bedasarkan Harga Privat di Daerah Penelitian, Tahun 2019

\begin{tabular}{|c|c|c|c|}
\hline \multirow{2}{*}{ Uraian } & \multicolumn{3}{|c|}{ Finansial (Harga Privat) } \\
\hline & Input Non Tradebale & Input Tradeable & Total \\
\hline \multicolumn{4}{|l|}{ Input Produksi } \\
\hline Bibit & 565.953 & & 565.953 \\
\hline \multicolumn{4}{|l|}{ Pupuk } \\
\hline 1. Urea & 552.737 & 225.766 & 778.504 \\
\hline 2.KCL & 722.221 & 294.991 & 1.017 .213 \\
\hline 3.NPK & 667.186 & 275.512 & 939.699 \\
\hline \multicolumn{4}{|l|}{ Obat-obatan } \\
\hline 1.Gramaxone & 37.748 & 8.889 & 46.638 \\
\hline 2.Rondap & 28.226 & 6.646 & 34.873 \\
\hline \multicolumn{4}{|l|}{ Biaya Peralatan } \\
\hline Cangkul & 21.792 & & 21.792 \\
\hline Dodos & 16.187 & & 16.187 \\
\hline Egrek & 12.290 & & 12.290 \\
\hline Angkong & 34.285 & & 34.285 \\
\hline Tojok & 19.327 & & 19.327 \\
\hline Gancu & 6.617 & & 6.617 \\
\hline \multicolumn{4}{|l|}{ Tenaga Kerja } \\
\hline Dalam Keluarga & 558.781 & & 558.781 \\
\hline Luar keluarga & 3.743 .504 & & 3.743 .504 \\
\hline Jumlah & 6.986 .854 & 811.804 & 7.795 .663 \\
\hline
\end{tabular}

Tabel 4 menunjukkan bahwa biaya sumberdaya domestik bedasarkan harga privat atau harga pasar total jumlah biaya sumberdaya domestik sebesar 6,98 juta rupiah biaya sumberdaya asing sebesar Rp.811.804/ha diperoleh dari alokasi komponen asing dari pupuk urea sebesar Rp.225.766, pupuk KCL sebesar Rp.294.991, dan pupuk NPK sebesar Rp.275.512 serta pestisida jenis gramaxone sebesar Rp.8.889 dan Rondap sebesar Rp.6.646.

Hasil perhitungan indikator rasio pengukuran daya saing menghasilkan nilai PCR untuk usahatani sawit di daerah penelitian kurang dari satu yaitu sebesar 0,1399 menunjukkan usahatani sawit di Kecamatan Sekernan efisien secara finansial dan memilki keunggulan kompetitif. Nilai 0,1399 mempunyai arti bahwa untuk menghasilkan satu satuan nilai tambah output pada harga privat hanya membutuhkan sumber daya domestik sebesar $13,99 \%$. Atau setiap satu satuan rupiah produksi yang dihasilkan akan memberikan nilai tambah secara finansial (harga privat) sebesar 0,1399 rupiah. Keuntungan privat yang dimiliki oleh petani dalam usahatani sawit lebih dari nol atau bernilai positif yaitu sebesar Rp.22.838.066 menunjukkan usahatani sawit di daerah penilitian layak secara finansial dan menguntungkan. Sejalan dengan penelitian yang dilakukan oleh Jawari et.al (2017:94) bahwa nilai PCR usahatani sawit adalah sebesar 0,24 atau PCR $<1$. dengan nilai PCR sebesar 0,24 maka usahatani kelapa sawit memiliki kemampuan lebih dalam membiayai faktor domestiknya. Dengan kata lain bahwa pendapatan yang dihasilkan mampu menutupi biaya produksi.

\section{Analisis Sensitivitas}

Dampak perubahan peningkatan harga pupuk terhadap keunggulan komparatif dan keunggulan kompetitif usahatani sawit di Kabupaten Muaro Jambi tidak berpengaruh terlalu besar terhadap biaya usahatani yang dikeluarkan petani hanya saja penerimaan yang diterima petani akan sedikit berkurang dikarenakan peningkatan harga pupuk tersebut. Apabila terjadi peningkatan harga pupuk sebsar $25 \%$ dan $50 \%$ maka usahatani di daerah penelitian masih memiliki daya saing. Dilihat dari 
kenaikan harga pupuk sebesar 25\% DRCR sebesar 0,27 dan PCR sebesar 0,14. Kenaikan harga pupuk sebesar $50 \%$ DRCR sebesar 0,28 dan PCR sebesar 0,14. Penelitian ini sejalan dengan Fery (2014) bahwa nilai DRCR $<1$ dan PCR $<1$ dimana usahatani masih mengutungkan secara finansial dan memiliki keunggulan kompetitif dan komparatif yang artinya masih memilki daya saing.

\section{Kebijakan Pemerintah Terhadap Usahatani Sawit}

Kebijakan pemerintah dapat dilihat dari indikator rasio yang dihitung berdasarkan komponen tabel PAM , Tabel 5:

Tabel 5. Idikator Rasio Kebijakan Pemerintah Terhadap Usahatani Sawit di Daerah Penelitian, Tahun 2019

\begin{tabular}{lr}
\hline Indikator & \multicolumn{1}{c}{ Nilai } \\
\hline Keuntungan Privat=A-B-C & 42.953 .200 \\
Keuntungan Sosial = E-F-G & 22.838 .066 \\
Rasio Sumber Daya Domestik $(\mathrm{DRCR})=\mathrm{G} /(\mathrm{E}-\mathrm{F})$ & 0,2734 \\
Rasio Biaya Privat $(\mathrm{PCR})=\mathrm{C} /(\mathrm{A}-\mathrm{B})$ & 0,1399 \\
\hline
\end{tabular}

Keuntungan privat dan keuntungan sosial usahatani sawit di Kecamatan Sekernan menunjukan nilai positif, itu berarti usahatani sawit layak untuk diusahakan atau dikembangkan. Keuntungan ditingkat harga privat sebesar 42,95 juta rupiah juta rupiah per tahun/ha, sedangkan penerimaan ditingkat harga sosial sebesar 22,83 juta rupaih per tahun/ha. Nilai divergensi yang positif yaitu sebesar 17,85 juta rupiah artinya kebijakan pemerintah telah mampu memberikan kontribusi yang efektif terhadap penerimaan dan pengeluaran dalam usahatani sawit di Kecamatan Sekernan. Hal ini sejalan dengan penelitian Palupi Permata,R (2013), dengan nilai divergensi yang bernilai postif sebesar 153,248 juta rupiah per hektar.

Hasil perhitungan indikator rasio pengukur daya saing menghasilkan nilai DRCR untuk usahatani sawit di daerah penelitian kurang dari satu yaitu sebesar 0,2734 menunjukkan usahatani sawit di Kecamatan Sekernan efisien dalam penggunaan sumberdaya domestik dan memiliki keunggulan komparatif. Nilai 0,2734 mempunyai arti bahwa untuk menghasilkan satu satuan nilai tambah output pada harga sosial hanya membutuhkan sumberdaya domestik sebesar $27,34 \%$ atau setiap satu satuan rupiah produksi yang dihasilkan akan memberikan nilai tambah secara ekonomis (harga sosial) sebesar 0,2734 rupiah. Hal ini sejalan dengan penelitian yang dilakukan oleh Aprizal et.al (2013:143) bahwa usahatani sawit memiliki nilai DRCR $<1$ yaitu 0,72 . Semakin rendah nilai koefisien DRCR berarti desa tersebut mampu bertahan walaupun tanpa bantuan pemerintah karena memilki sumber daya domestik yang diperlukan bagi pengembangan komoditas kelapa sawit.

Hasil perhitungan indikator rasio pengukuran daya saing menghasilkan nilai PCR untuk usahatani sawit di daerah penelitian kurang dari satu yaitu sebesar 0,1399 menunjukkan usahatani sawit di Kecamatan Sekernan efisien secara finansial dan memilki keunggulan kompetitif. Nilai 0,1399 mempunyai arti bahwa untuk menghasilkan satu satuan nilai tambah output pada harga privat hanya membutuhkan sumber daya domestik sebesar $13,99 \%$. Atau setiap satu satuan rupiah produksi yang dihasilkan akan memberikan nilai tambah secara finansial (harga privat) sebesar 0,1399 rupiah. Keuntungan privat yang dimiliki oleh petani dalam usahatani sawit lebih dari nol atau bernilai positif yaitu sebesar Rp.22.838.066 menunjukkan usahatani sawit di daerah penilitian layak secara finansial dan menguntungkan. Sejalan dengan penelitian yang dilakukan oleh Jawari et.al (2017:94) bahwa nilai PCR usahatani sawit adalah sebesar 0,24 atau PCR $<1$. dengan nilai PCR sebesar 0,24 maka usahatani kelapa sawit memiliki kemampuan lebih dalam membiayai faktor domestiknya.

\section{KESIMPULAN}

Usahatani kelapa sawit memiliki daya saing ditinjau dari indikator keunggulan komparatif dan kompetitif. Keunggulan Komparatif dilihat dari Domestic Resources Cost Ratio (DRCR) dengan nilai $0,2734<1$ dan keunggulan Kompetitif dari Private Cost Ratio (PCR) dengan nilai 0,1399<1. Keuntungan sosial dan keuntungan privat di lokasi penelitianbernilai positif artinya pemerintah telah mampu menerapkan kebijakan di daerah penelitian. Hasil analisis sensitivitas usahatani kelapa sawit tetap memiliki daya saing walaupun terjadi peningkatan harga pupuk sebesar $25-50 \%$. Artinya kenaikan harga tidak sensitif terhadap naik atau turunya harga pupuk. 


\section{SARAN}

Perlu adanya upaya peningkatan harga, peningkatan produktivitas dengan memperbaiki pemeliharaan tanaman dan mengurangi pengeluaran usahatani yang harus dibayarkan petani. Kebijakan Pemerintah daerah Kecamatan Sekernan selain memberikan pupuk subsidi, pemerintah dapat juga memberikan dukungan dalam bentuk penyediaan (subsidi) bibit yang bersertifikat, sehingga produktivitas kelapa sawit petani rakyat dapat ditingkatkan, selain itu petani serta penyuluh pertanian khususnya perkebunan kelapa sawit dapat dioptimalkan dalam menuju produktivitas kelapa sawit yang meningkat.

\section{DAFTAR PUSTAKA}

Aprizal, Asriani, Putri Suci, dan Sriyoto. Analisis Daya Saing Usahatani Kelapa Sawit Kabupaten Mukomuko. Jurnal Agribisnis. Vol 12, No 2 September 2013 : 133-146. Fakultas Pertanian. Universitas Bengkulu. Bengkulu

Jawari, Ani Muani, Radian. 2017. Analisis Daya Saing Usahatani Kelapa Sawit Rakyat di Kecamatan Subah Kabupaten Sambas. Jurnal Sosial Ekonomi Agribisnis Vol 6, No 1 April 2017 : 85-100. Fakultas Pertanian Universitas Tanjungpura Pontianak. Pontianak.

Kementerian Pertanian. 2016. Outlook Sawit Komoditas Pertanian Subsektor Perkebunan. ISSN : 1907-1507. Diakses pada tanggal 15 Februari 2019

Murtiningrum, Ferry, Asniani, Putri Suci dan Badrudin, Redy. 2014. Analisis Daya Saing Usahatani Kopi Robusta (Coffea Canephora) di Kabupaten Rejang Lebong. Jurnal Agribisnis Vol 13, No 1 Maret 2014 : 1-14. Fakultas Pertanian Universitas Bengkulu. Bengkulu.

Palupi Rahmi, P. Kuswanti Suwarsinah, Rr.Heny dan Winandi, Ratna. 2013. Analisis Daya Saing dan Dampak Kebijakan Pemerintah Terhadap Komoditas Teh. Jurnal Fakultas Pertanian dan Manajemen Institut Pertanian Bogor. Diakses Pada Tanggal 21 Oktober 2019.

Sari, Widia Rosdiana. 2018. Analisis Daya Saing Komoditas Karet di Kabupaten Batanghari. Skripsi. Fakultas Pertanian. Universitas Jambi. Jambi 